\title{
Investigating the Maturity of Incident Investigations of the Ghanaian Mining Industry and Its Effect on Safety Performance
}

\author{
Eric Stemn ${ }^{1,2, * \mathbb{C}}$, Carmel Bofinger ${ }^{1}$, David Cliff ${ }^{1}$ and Maureen E. Hassall ${ }^{3}$ \\ 1 Minerals Industry Safety and Health Centre, Sustainable Minerals Institute, The University of Queensland, \\ Brisbane, QLD 4072, Australia; c.bofinger@uq.edu.au (C.B.); d.cliff@mishc.uq.edu.au (D.C.) \\ 2 Environmental and Safety Engineering Department, University of Mines and Technology, P.O. Box 237, \\ Tarkwa WT000, Ghana \\ 3 The School of Chemical Engineering, The University of Queensland, Brisbane, QLD 4072, Australia; \\ m.hassall1@uq.edu.au \\ * Correspondence: e.stemn@uq.edu.au; Tel.: +61-416-399-139
}

Received: 14 November 2018; Accepted: 7 January 2019; Published: 10 January 2019

\begin{abstract}
Effective incident investigations have been recognised as a vital means of improving safety. Nevertheless, there has been little attempt to link incident investigations to actual safety performance. In this study, a framework for assessing the maturity of incident investigations and identifying areas for improvements is described. The framework was developed based on a literature review and interviews with 41 investigators across five large-scale Ghanaian gold mines. The framework consists of 20 elements across four dimensions and five maturity levels. The dimensions (investigator competencies, system of investigation, stages of investigation and post-investigation findings) consider the most relevant aspects of practical investigation and for each dimension, elements that are more specific were defined across five maturity levels. Mapping the interview data collected from five mines into a maturity framework highlighted that the mines occupied different positions on the framework. Some occupied the advanced levels consistently and others consistently occupied the lower levels. Applying the interview data to the framework also identified priority areas for improvement. Finally, the maturity scores derived from mapping interview data onto the framework were correlated with the incidence rates of the mines to determine if any relationship existed between the two variables. The low incidence rate mines had higher maturity scores and the high incidence rate mines had lower maturity scores. It was found that the method was effective in practice, giving clear indications of areas where improvements are needed.
\end{abstract}

Keywords: maturity framework; incident investigation; incidence rate; investigator competencies

\section{Introduction}

In recent years, there has been increasing research interest in the field of incident investigation and learning from incidents (LFI), particularly the use of learning from incidents to improve organisational safety [1-3]. Over the years, there has been notable improvement in safety science, specifically incident investigations, in both theory and practice. Incident investigation approaches are advancing to capture the growing recognition that most industries, including mining are complex socio-technical systems and that the occurrence of unwanted events in complex systems can have multiple causes that emerge from a range of organisational elements [4,5]. Accident causation models have evolved from focusing on parts of a system [6] to an emphasis on the entire system interactions [7-10]. Similarly, the method of incident/accident analysis used for searching for the causes of incidents/accidents has advanced from an emphasis on the proximate causes to a focus on systemic factors responsible for the proximate 
causes. However, studies show that the practice of incident investigations is yet to fully embrace these theoretical innovations [11,12] and others have questioned the effectiveness of practical incident investigations [2,13]. Within the literature, explanations abound as to why the effectiveness of incident investigations is hindered. These include but are not limited to the flawed thinking of incident investigators, political considerations and organisational resources [12].

The existing literature indicates that organisations adopts different processes and practices to manage and learn from past incidents with the aim of preventing future incidents [11,14]. Previous studies indicate that organisations learn differently from safety incidents, and some are more effective in how they learn from incidents than others [2,15]. The analysis of practical incident investigations in five Ghanaian large-scale mines revealed that the mines had different investigation processes and practices. There were also differences in terms of how investigators were conducting their investigations [16]. Investigators at some mines had received no formal incident investigation training and lacked knowledge of accident causation models and investigation methods, whereas investigators at other mines had been trained in the model/method of investigation used at the mine. Interestingly this training did not seem to include how to detect and address issues of motivational and cognitive biases that can impact the quality of an investigation and the recommendations produced [16,17]. At some mines investigations were conducted to satisfy legal/regulatory requirements, while at others, incident investigations were accepted as an important part of the work process focusing on continuous improvement. These results suggested the existence of different levels of incident investigation maturity across the mines. The results of that study together with a review of the incident investigations literature have led to the formulation of an incident investigation maturity framework that can be used by organisations to self-assess the maturity of their investigation. However, the framework lacked empirical validity, reliability and usability. This present study provides details about the development of the framework, its validity and demonstrate how it can used. The investigation maturity model presented here is similar to other safety maturity models, particularly the popularised safety culture maturity model [18]. Again, this study was motivated by our previous related study, which examined the relationship between the safety culture maturity and safety performance of Ghanaian mines [19]. We observed that for the mines that we sampled, a strong negative correlation existed between their incidence rates and their safety culture maturity scores, suggesting that a more mature safety culture can be a factor in reducing incidents. Therefore, in this present work, we equally sought to investigate whether matured incident investigations can be a factor in improving safety performance.

Although there is currently a growing interest in the use of incident investigations for improving safety, there is limited empirical research that links the effectiveness of incident investigation processes and practices to actual safety performance metrics. This study, first, describes the incident investigation maturity framework and determines the positions of the participating mines on the framework. Secondly, the study considered if there is any correlation between the safety performances of the mines and their investigation maturities.

\section{Theoretical Underpinnings}

The incident investigation maturity framework described in this study was developed based on existing safety maturity models and the incident investigations literature. Maturity models have been conceptualised as consisting of specific maturity levels/stages that evaluates the effectiveness/successfulness of an analysed unit (usually an organisation) through different set of multi-dimensional criteria [20-23]. The maturity model concept has been applied in safety culture to define on a continuum the level of importance an organisation places on safety values, beliefs, attitude and information [18,23-25]. Fleming [26] points out that organisations can sequentially progress through the different safety culture maturity levels by building on the strengths and overcoming the weaknesses of previous maturity levels. The safety culture maturity model is not only an assessment tool but also can be used as an improvement tool especially when supported by a variety of data 
sources including interviews, questionnaires surveys and safety audits [26-28]. A popular use of the maturity model in safety is the safety culture maturity framework, which consist of a range of key aspect of safety culture across different levels of maturities [19,26,29-31]. A key feature of such frameworks is a matrix/grid containing statements for the characteristic traits of each aspects of performance for each maturity level [32]. Maier, Moultrie [28] and Becker, Knackstedt [20] have further indicated that a fundamental advantage of a maturity framework/matrix lies in its simplicity and ability to generate results that reveal priority areas to support the development of improvement measures to attain higher maturity levels. The incident investigation literature indicates that different organisations learn differently from past incidents, suggesting the existence of different investigation maturity/effectiveness across different organisations. Insights from the safety maturity models were used to develop an assessment tool to help organisations determine the maturity of their investigation and to identify weak and priority areas to enable the development of improvement interventions.

Most organisations have a formal incident investigation system and practical activities to obtain lessons from past incidents for individual and organisational learning [2,11,14]. The system of investigation refers to formal policies, processes and procedures used to ensure that learning opportunities are not lost, such as the types of incident investigated and how to investigate them, who is responsible for investigating what, and when to initiate and complete an investigation among others. The investigation activities on the other hand represent the typical stages/activities that most investigators encounter when conducting investigations, such as data collection, representation and analysis, making recommendations for improvement, disseminating lessons and follow-up [11,15,33]. The effectiveness of the investigation system and activities are important for the quality of lessons that can be obtained. Similarly, the use of the identified lessons is important for learning. Since an actual investigation is a process, each activity/stage produces a result that is a vital input for the next activity/stage of the investigation. Therefore, to improve learning, an organisation must periodically assess the effectiveness of their investigation systems and activities $[3,15,34,35]$. This will help identify weak areas so that improvement interventions can be specific. However, there seems to be a lack of guidance information available to help practitioners assess the effectiveness of their investigations. This paper begins to address this gap by testing the application of the safety maturity model with empirical information obtained from five Ghanaian mining companies.

\section{Methods}

\subsection{Development of a Framework for Assessing the Maturity of Incident Investigations}

The incident investigation maturity framework described here is based on Hudson's (2001) 5-level safety culture maturity model and the incident investigations literature. The purpose was to:

- provide a normative framework within which to consider what constitutes a "less-matured" or a "matured" incident investigation; and

- demonstrate how incident investigations can be improved within the context of the framework by identifying areas needing improvement.

The framework is a self-assessment tool that can be used by individuals and organisations to assess the maturity/effectiveness of their incident investigations. Prerequisites for using the framework is that there must be an existing formal documented incident investigation system and activities to assess and the person doing the assessment must be knowledgeable of the existing investigation system and activities. The framework was developed through review of the incident investigations literature and in-depth individual and group face-to-face interviews with 41 incident investigators from five gold mining companies operating in Ghana. Four of the companies were multinational and one was a foreign-owned but not multinational company. All the five mines and individual interviewees gave their informed consent for inclusion before they participated in the study. The study was conducted in accordance with the Declaration of Helsinki, and the Sustainable Mineral Institutes (University of 
Queensland) Student Research Ethics Committee gave ethical clearance with an approval number of 16-004.

The interviewees had diverse investigation experience of the Ghanaian mining industry. They came from three hierarchical levels, namely frontline managers (e.g., safety supervisors), middle managers (e.g., drill and blast superintendent) and top managers (e.g., engineering manager). Interviewing this range of employees with diverse first-hand experience of how incident investigations are conducted ensured that a variety of perspectives was captured. The interviews were conducted following a semi-structured guide developed from the incident investigation literature and had the following focus:

- Investigator competencies: formal investigation trainings, knowledge of accident causation models and investigation methods, professional networks to support investigation.

- System of investigation: purpose of investigation, types of incident investigated and how they are investigated, what initiates investigations, who investigates, investigation timelines.

- Stages of investigation: data sources for investigations, data analysis, causes commonly identified, nature of remedial measures recommended.

- Post-investigation findings: questions about review of investigation reports/findings, extent and channels for disseminating lessons, use of post-investigation findings.

Interviewees were asked to describe how they/their mine functions in terms of the four topics shown above. The interviewees were not asked to comment on each of the aspects covered at the different levels of investigation maturity, rather they were requested to describe their own experiences with respect to various aspects of the four topics. The maturity levels emerged during data analysis. During the interviews, consensus emerged and saturation was achieved in that different and new ideas ceased to emerge from the interviews [31].

The interview data was first grouped under the four broad categories, and each category analysed through qualitative content analysis (QCA) to identify subcategories [36-41]. This led to the identification of 20 subcategories under the four categories by constantly comparing the codes. After identifying the 20 subcategories, each participant's response to each of the 20 subcategories was analysed. During this analysis, it was observed that the participants' responses were varied, even across the same mine. The results of the participants' responses to each of the 20 subcategories showed that the participants and the mines had different maturity levels with respect to their investigations. Some mines and participants' investigation training processes and practices were not well developed or "less mature" than others who had more developed or "more mature" systems and activities. This supported the adoption of the maturity framework concept to illustrate the different maturity levels with respect to incident investigations across the mines. Based on the insights from the research, the incident investigations and the safety maturity framework literature [24,31,42], an incident investigation maturity framework was formulated to support investigators and organisations to self-assess the maturity or effectiveness of their investigation.

Hudson's (2001) 5-level maturity model was adopted due its depth and wide application across several industries. However, the terms adopted were those that are familiar in the mining industry [19,43-45]. The framework consist of three components namely, (1) four dimensions (2) and 20 elements across (3) five maturity levels as shown Figure 1. The dimensions were the four major topics discussed during interviews with the investigators. The elements were the sub-categories identified through content analysis. Each element belongs to one of the four dimensions. Therefore, whereas the four dimensions purely emerged from the incident investigations literature [11,12], the 20 elements were determine from both the literature and interviews through an integrated inductive and deductive approach. The maturity levels are seen as overlapping, to recognise the possibility of a mine being at different maturity levels across the various incident investigation elements. Through content analysis, statements were identified in relation to each of the five maturity levels for each of the elements. This resulted in a grid containing brief narratives of the participants' responses at each of the five 
stages of incident investigation maturity for each of the elements. Table 1 is the maturity framework for the investigator competencies dimension. As shown in Table 1, the framework is structured as a grid or matrix where the five levels of maturity are allocated against the elements of the dimension, resulting in a series of cells. Each cell, therefore, contains descriptive text indicating the characteristics of each maturity level for each element. To be able to express the maturity of an element numerically, a rating scale was created based on the different maturity levels. As shown in Figure 1 and Table 1, the rating scale is such that 1 represent the lowest (Basic) level and 5 the highest (Resilient) maturity level. The other dimensions were treated similarly as shown in the Appendices A-D.

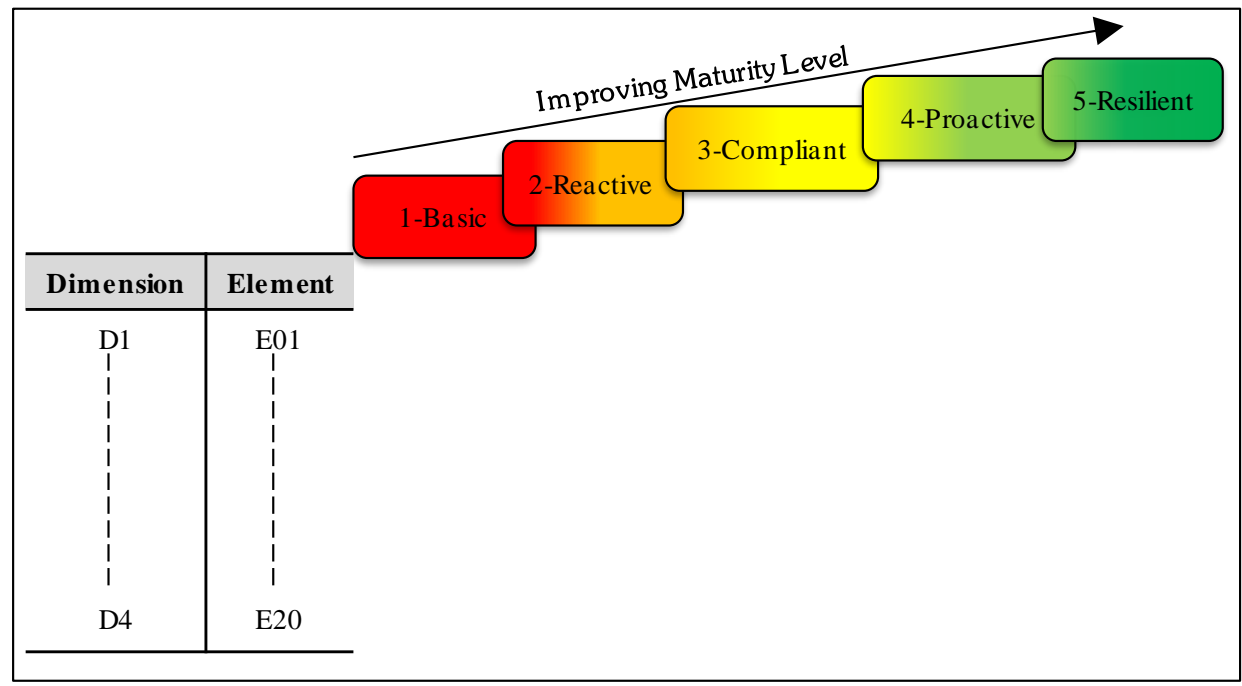

Figure 1. Component of the incident investigations maturity framework.

\subsection{Determining Face and Content Validity of the Framework}

There was the need to determine the extent to which the framework covered all necessary aspects of practical investigation in the Ghanaian mining industry (GMI), and whether it measured what it intended measuring. Mineworkers with diverse incident investigations experience in the GMI were consulted to determine the face and content validity of the framework. The framework was presented to 20 investigators who took part in the initial interviews and 10 other investigators who were not part of the initial interviews through emails, followed by phone/skype calls to further explain the framework. The purpose of this second contact was to review the framework to determine whether the content made sense to those who would be using it and to determine whether the elements of the framework rightly captured all relevant aspects of practical investigations. The participants were requested to indicate whether the framework covers all the important aspects of their investigations and state any aspect that were not covered. They were also asked to indicate the extent to which the framework was coherent and whether the statements under each of the maturity levels were accurate and understandable. Twenty-four out of the 30 investigators agreed that the framework covered the relevant aspect of their investigations; four did not reply to the request to review the framework; and the remaining two suggested some portions of the framework should be revised. There was agreement concerning the coherence of the framework and the accuracy of the description of the different maturity levels. Some of the investigators provided comments on some of the elements and descriptions of the maturity levels that were used to refine the framework. The final framework after the validity testing is what is shown in the Appendices A-D. 
Table 1. Framework for assessing maturity of investigator competencies.

\begin{tabular}{|c|c|c|c|c|c|c|}
\hline \multicolumn{2}{|c|}{ Component of Framework } & \multicolumn{5}{|c|}{ Maturity Level } \\
\hline Dimension & Element & 1-Basic & 2-Reactive & 3-Compliant & 4-Proactive & 5-Resilient \\
\hline \multirow{3}{*}{$\begin{array}{l}\text { Investigator } \\
\text { competencies }\end{array}$} & $\begin{array}{l}\text { Investigation training } \\
\text { (E1) }\end{array}$ & $\begin{array}{l}\text { No formal training is } \\
\text { given, investigator are on } \\
\text { their own to skill-up }\end{array}$ & $\begin{array}{l}\text { Basic formal investigation } \\
\text { training (including how } \\
\text { to conduct interviews, } \\
\text { data collection, } \\
\text { reporting findings) }\end{array}$ & $\begin{array}{l}\text { Investigation training } \\
\text { is given, including } \\
\text { general knowledge } \\
\text { and investigation } \\
\text { method used at site }\end{array}$ & $\begin{array}{l}\text { Skill-based investigation } \\
\text { training and development } \\
\text { is given, including how to } \\
\text { identify and manage } \\
\text { motivational and } \\
\text { cognitive biases }\end{array}$ & $\begin{array}{l}\text { Regular investigation training } \\
\text { and development tailored to } \\
\text { individual needs identified } \\
\text { through evaluation, with } \\
\text { ongoing coaching, including } \\
\text { how to identify and manage } \\
\text { motivational and } \\
\text { cognitive biases }\end{array}$ \\
\hline & $\begin{array}{c}\text { Knowledge of } \\
\text { causation } \\
\text { models/investigation } \\
\text { methods } \\
\text { (E2) } \\
\end{array}$ & $\begin{array}{c}\text { No knowledge of } \\
\text { academic causation } \\
\text { models and } \\
\text { investigation methods }\end{array}$ & $\begin{array}{c}\text { Knowledge of } \\
\text { investigation method } \\
\text { used at site, but lacks } \\
\text { knowledge of underlying } \\
\text { causation model }\end{array}$ & $\begin{array}{l}\text { Knowledge of } \\
\text { investigation method } \\
\text { and underlying } \\
\text { causation model in } \\
\text { use at site }\end{array}$ & $\begin{array}{c}\text { Exposed to a variety of } \\
\text { models and methods, } \\
\text { however, understands the } \\
\text { model/method used at the } \\
\text { site than the others }\end{array}$ & $\begin{array}{l}\text { In-depth knowledge of severa } \\
\text { models and methods, } \\
\text { recognises their differences and } \\
\text { uses them appropriately }\end{array}$ \\
\hline & $\begin{array}{l}\text { Professional networks } \\
\text { to support } \\
\text { investigations } \\
\text { (E3) }\end{array}$ & $\begin{array}{l}\text { Investigator does not } \\
\text { belong to any } \\
\text { professional network to } \\
\text { support } \\
\text { investigation practices }\end{array}$ & $\begin{array}{l}\text { Investigator is part of a } \\
\text { local investigators } \\
\text { network, however } \\
\text { knowledge-sharing is ad } \\
\text { hoc, limiting its } \\
\text { effectiveness }\end{array}$ & $\begin{array}{l}\text { Investigator is part of } \\
\text { a proactive local } \\
\text { investigators network } \\
\text { where there is regular } \\
\text { knowledge transfer }\end{array}$ & $\begin{array}{l}\text { Investigator participate in } \\
\text { professional networks both } \\
\text { local and outside his/her } \\
\text { own organisation to learn } \\
\text { from other sites/domain }\end{array}$ & $\begin{array}{l}\text { Investigator regularly } \\
\text { participates in several } \\
\text { investigators networks locally } \\
\text { and outside organisation to } \\
\text { continuously learn from others } \\
\text { and improve competencies }\end{array}$ \\
\hline
\end{tabular}




\subsection{Determining the Maturity of Incident Investigations across Five Mines}

In order to determine where the mines were on the maturity framework, the final framework was applied to interview responses. This was possible because of the use of semi-structured interviews, which ensured that all the participants spoke about the major topics of the interviews, although they provided different details. In determining the maturity levels of the mines, the descriptions across the five maturity levels for each element were compared with the actual responses the participants provided in the interviews, and the description best reflecting the participants' response was selected. For example, to determine the maturity of a participant's incident investigation training, his/her response to the question about the nature of formal investigation training received from the mine was compared with each of the descriptions of the 5 levels of maturity (from basic to resilient) under the investigation training element. The level best matching the participant's response was selected and indicated with the appropriate number (that is 1 for basic and 5 for resilient). This process of comparing participants' responses to the maturity level descriptions of the framework and selecting the level best matching the participants' response was conducted for all 41 interviews across all 20 elements of the framework. The first author and another analyst independently did this and compared their results to resolve any discrepancy.

The output from the analysis resulted in numerical ( 1 to 5$)$ data for each of the elements of the framework for each interview participant. After assessing each element, a mean value of all the elements was calculated to represent the overall maturity of investigations for each participant. In addition, the mean of the total number of responses from each mine for each of the elements was determined as the level of maturity of the elements for the mine.

\subsection{Association between Maturity of Incident Investigations and Safety Performance}

Apart from determining the levels of investigation maturity across the mines, this study also sought to examine if any relationship existed between the investigation maturity levels of the mines and their safety performance metrics. Incidence data, which is the monthly recordable injuries [46] from 2012 to 2016 was collected from the mines. The severity of the incidents was similar across the mines. Specifically, at all the mines, the frequency of less severe injuries such as medical treated injuries (MTI) and restricted work injuries (RWI) exceeded fatalities and lost time injuries (LTI) as shown in Table 2. The incidence rate per 100 workers was calculated based on the Australian Standard [47] for workplace injury and disease recording. One-way analysis of variance (ANOVA) was conducted to determine whether the differences in the incidence rate were statistically significant. Finally, the five-year incidence rate of the mines was combined into a single value, similarly the incident investigation maturity scores of the elements. Then, correlation analysis was conducted to determine whether any of the elements of the maturity framework correlated with the incidence rate.

Table 2. Comparison of injury severity across the mines.

\begin{tabular}{ccccc}
\hline Mine & Fatality & Lost Time Injury & Other Injuries & Total \\
\hline A & 2 & 4 & 54 & 60 \\
B & 2 & 7 & 51 & 60 \\
C & 1 & 8 & 51 & 60 \\
D & 2 & 12 & 46 & 60 \\
E & 1 & 5 & 54 & 60 \\
Whole cohort & 8 & 36 & 256 & 300 \\
\hline
\end{tabular}

\section{Results}

\subsection{Respondents' Characteristics}

There were more respondents in Mines C (12) and A (10) than the other mines (Table 3). The number of respondents from each of the mines reflects the number of employees at the various 
mines. All investigators present on site at the time of the fieldwork were interviewed. Table 3 shows that there were more male respondents than females, which is representative of the male-female worker ratio of the industry [48,49]. Regarding the hierarchical levels of the participants, frontline supervisors were more represented than their counterpart middle and top managers. All the top manager respondents came from Mines A (2), C (1) and E (2). Across the mines, about $80 \%$ of the respondents had core safety jobs. In addition, concerning the number and recency of their investigations, over $80 \%$ were investigating an incident either at the time of the interviews or at most a year ago, and over $50 \%$ had been involved in at least 31 investigations.

Table 3. Characteristics of interview respondents.

\begin{tabular}{|c|c|c|c|c|c|c|}
\hline \multirow{2}{*}{ Characteristics } & \multicolumn{6}{|c|}{ Number (Percentage) of Responses from Mines } \\
\hline & Mine A & Mine B & Mine C & Mine D & Mine E & Whole Cohort \\
\hline \multicolumn{7}{|l|}{ Gender } \\
\hline Female & $2(20)$ & $2(25)$ & $3(25)$ & $1(16.7)$ & $0(0)$ & $8(19.5)$ \\
\hline Male & $8(80)$ & $6(75)$ & $9(75)$ & $5(83.3)$ & $5(100)$ & $33(80.5)$ \\
\hline \multicolumn{7}{|l|}{ Education level } \\
\hline Post-secondary & $1(10)$ & $1(12.5)$ & $2(16.7)$ & $0(0)$ & $0(0)$ & $4(9.8)$ \\
\hline First degree & $6(60)$ & $7(87.5)$ & $10(83.3)$ & $6(100)$ & $5(100)$ & $34(82.9)$ \\
\hline Postgraduate & $3(30)$ & $0(0)$ & $0(0)$ & $0(0)$ & $0(0)$ & $3(7.3)$ \\
\hline \multicolumn{7}{|l|}{ Level in organisation } \\
\hline Frontline supervisor & $6(60)$ & $6(75)$ & $9(75)$ & $6(100)$ & $0(0)$ & 27 (65.9) \\
\hline Middle manager & $2(20)$ & $2(25)$ & $2(16.7)$ & $0(0)$ & $3(60)$ & $9(22)$ \\
\hline Top manager & $2(20)$ & $0(0)$ & $1(8.3)$ & $0(0)$ & $2(40)$ & $5(12.2)$ \\
\hline \multicolumn{7}{|l|}{ Core job } \\
\hline With core safety job & $8(80)$ & $6(75)$ & $12(83)$ & $6(100)$ & $4(80)$ & $34(83)$ \\
\hline Without core safety job & $2(20)$ & $2(25)$ & $2(17)$ & $0(0)$ & $1(20)$ & $7(17)$ \\
\hline \multicolumn{7}{|l|}{ Last investigation } \\
\hline Currently & $3(30)$ & $1(12.5)$ & $4(33.3)$ & $4(66.7)$ & $1(20)$ & $13(31.7)$ \\
\hline$<1$ year & $6(60)$ & $5(62.5)$ & $5(41.7)$ & $2(33.3)$ & $3(60)$ & $21(51.2)$ \\
\hline $1-2$ years & $1(10)$ & $1(12.5)$ & $0(0)$ & $0(0)$ & $1(20)$ & $3(7.3)$ \\
\hline$>2$ years & $0(0)$ & $1(12.5)$ & $3(25)$ & $0(0)$ & $0(0)$ & $4(9.8)$ \\
\hline \multicolumn{7}{|l|}{ No of investigation } \\
\hline$>10$ & $1(10)$ & $3(37.5)$ & $1(8.3)$ & $2(33.3)$ & $(0)$ & $7(17.1)$ \\
\hline $11-30$ & $2(20)$ & $1(12.5)$ & $3(25)$ & $4(66.7)$ & $2(40)$ & $12(29.3)$ \\
\hline $31-50$ & $3(30)$ & 1 (12.5) & $1(8.3)$ & $0(0)$ & $0(0)$ & $5(12.2)$ \\
\hline$>50$ & $4(40)$ & $3(37.5)$ & $7(58.3)$ & $(0)$ & $3(60)$ & $17(41.5)$ \\
\hline Age, yrs & $37( \pm 6)$ & $34( \pm 7)$ & $37( \pm 4)$ & $32( \pm 5)$ & $40( \pm 7)$ & $36( \pm 7)$ \\
\hline Total experience in mining, yrs & $10( \pm 5)$ & $8( \pm 5)$ & $9( \pm 5)$ & $5( \pm 1)$ & $13( \pm 9)$ & $9( \pm 6)$ \\
\hline Current mine experience, yrs & $8( \pm 5)$ & $5( \pm 2)$ & $8( \pm 3)$ & $5( \pm 1)$ & $6( \pm 2)$ & $6( \pm 4)$ \\
\hline Total experience in job title, yrs & $5( \pm 2)$ & $4( \pm 2)$ & $5( \pm 1)$ & $5( \pm 1)$ & $4( \pm 3)$ & $5( \pm 2)$ \\
\hline
\end{tabular}

\subsection{Incident Investigation Maturity Levels}

\subsubsection{Individual Responses}

Figure 2 shows the participants responses to each of the 20 elements of the framework, grouped according to the four dimensions. The figure illustrate characteristics from the lowest level (1-Basic) to the highest level (5-Resilient) of investigation maturity. 

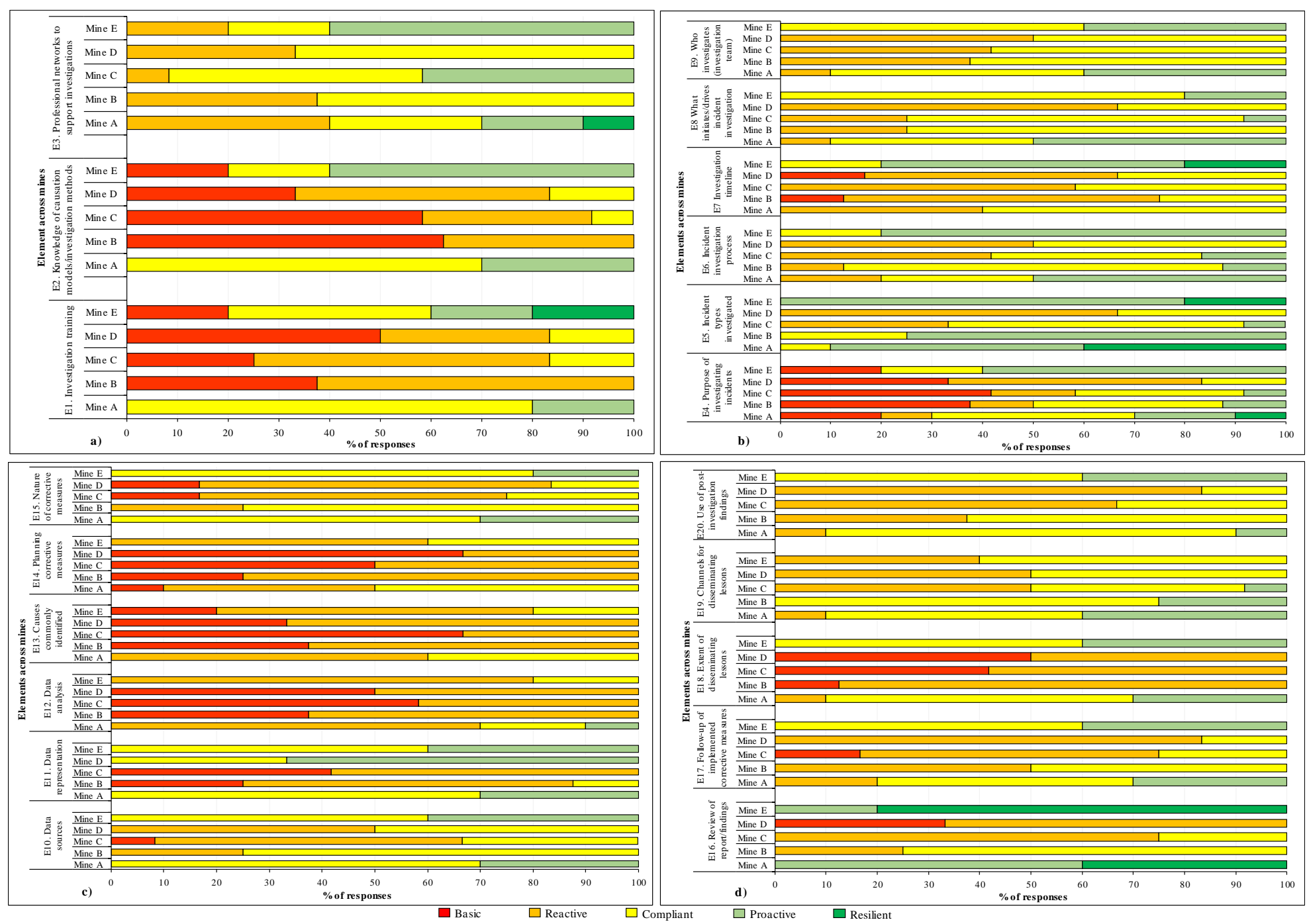

Figure 2. Incident investigations maturity levels across the five mines: (a) investigator competencies dimension, (b) system of investigation dimension, (c) stages of investigation dimension, (d) post-investigation findings. 
For the three elements of the investigator competencies dimension, the responses from Mines $\mathrm{B}, \mathrm{C}$ and D showed more characteristics of the lower levels (basic to compliant) of investigation maturity and no characteristics of the higher level. Mines A and E on the other hand appeared to be the most matured as responses from those mines showed the most characteristics of the higher maturity levels (proactive and resilient). Again, the elements E3 (professional networks to support investigations) seemed the most advanced among the three elements of the investigator competencies dimension, showing the most characteristics of the proactive and resilient level of maturity. Across all five mines, the participants responses to the elements measuring their investigation trainings (E1) and their knowledge of causation models and investigation methods (E2) was mostly at the basic and reactive levels. For the whole cohort, the modal choice was reactive, basic and compliant for the elements E1, E2 and E3, respectively.

Similarly, for the six elements of the system of investigation dimension, Mines A and E showed more characteristics of the highest level of investigation maturity, whereas Mines B, C, D showed more characteristics of the lowest levels of investigation maturity. Specifically, none of the responses from B, C and D occupied the resilient level, while some responses from A and E were at the resilient level from some elements, notably E4, E5 and E7. The element E4 (purpose of investigating incidents) seemed the least mature among all elements of the system of investigation dimension as it had the highest number of responses for the lowest level (basic and reactive) across all five mines. On the other hand, the element E5 appeared the best performing, having the highest number of responses of the upper levels (proactive and resilient) of maturity of all elements of the system of investigation dimension. When all the mines are considered as a single organisation, the modal maturity level was basic and compliant for the element E4, reactive for the element E7, compliant for the elements E6, E8 and E9 and proactive for the element E5.

For all six elements of the stages of investigation dimension, none of the responses from all five mines showed characteristics of the resilient level. Notably, all responses from the mines for E13 (causes commonly identified) and E14 (planning of corrective measures) occupied a maximum of the compliant level of maturity. In spite of these similarities in responses across the mines, the responses from Mines A and E for most of the elements showed more characteristics of the highest levels of maturity than the responses from B, C and D. The results further showed that Mine D is the most matured in terms of data representation (that is element E11), with all responses from the mine being at either the compliant or proactive level. For the whole cohort, the modal choice was below the proactive level for all the elements, specifically, compliant for the elements E10, E11 and E15 and reactive for the elements E12, E13 and E14.

For the elements focusing on post-investigation findings, the trend of the responses is similar to the other three dimensions. Responses from Mines B, C and D showed fewer characteristics of the upper level of investigation maturity, with responses from $A$ and $E$ showing the most characteristics of the upper levels of investigation maturity. The modal maturity level for the whole cohort was reactive for elements E16 to E18 and compliant for elements E19 and E20. Overall, the post-investigation findings dimension seemed the least advanced of all the four dimensions, as its elements showed most characteristics of the lower levels of maturity and the least characteristics of the upper levels of maturity.

\subsubsection{Averages of the Investigation Maturity Level of the Mines}

The mean position of each of the elements of the framework across the mines is shown in Table 4 and Figure 3. In Figure 3, the acronyms E1 to E20 represent the 20 elements of the investigation framework as shown in Table 4. It can straightaway be observed that there is close mapping between the mines with respect to weaker and stronger areas. None of the mines considered any of the elements to be basic (1) or resilient (5). For most of the elements, the mean scores of Mines A and E were higher than that of the other mines. Specifically, Figure 3 shows that the scores at A and E exceeded the scores of the whole cohort, while most of the scores at B, C, D were lower than the scores of the 
whole cohort, and in particular the scores of D and C were the weakest. Again, although Mines A and $\mathrm{E}$ had the highest scores for most elements, most of the elements had a slightly higher score at $\mathrm{E}$ than at A. Interestingly, although Mine D had the lowest score for most elements, it had the highest score for elements E11 (data representation). These results indicate that with respect to how incident investigations are conducted across the mines, the mines can generally be grouped into two, namely, less matured mines (B, C, D) and matured mines (A, E). For the less matured mines, the elements occupied between the middle basic and compliant levels, whereas for the matured mines, the elements occupied between the middle reactive and upper proactive levels. Some elements were also advanced than others. Comparing the elements, Figure 3 indicates that all the mines had the lowest scores for the elements measuring the competencies of investigators than the other elements, occupying either the middle basic or the compliant level, notably the investigation trainings (E1) and knowledge of causation models/investigation methods (E2) elements. Also, E14 (planning corrective measures) had the lowest scores across all the mines. For the whole cohort, the elements E5 (incident types investigated), E16 (review of investigation report/findings) and E18 (extent of disseminating lessons) occupied the highest position (lower to middle complaint), whereas the elements E1, E2 and E14 occupied the lowest position (upper basic to lower reactive).

Table 4. Mean value of incidence rate and investigation scores across the mines.

\begin{tabular}{lcccccc}
\hline \multirow{2}{*}{ Element of Framework and Incidence Rate } & \multicolumn{5}{c}{ Mine } \\
\cline { 2 - 7 } & A & B & C & D & E & Whole Cohort \\
\hline E1. Investigation training & 3.2 & 1.6 & 1.9 & 1.7 & 3.2 & 2.3 \\
E2. Knowledge of causation models/investigation methods & 3.3 & 1.4 & 1.5 & 1.8 & 3.2 & 2.2 \\
E3. Professional networks to support investigations & 3.0 & 2.6 & 3.3 & 2.7 & 3.4 & 3.0 \\
E4. Purpose of investigating incidents & 2.9 & 2.3 & 2.1 & 1.8 & 3.2 & 2.4 \\
E5. Incident types investigated & 4.3 & 3.8 & 2.8 & 2.3 & 4.2 & 3.4 \\
E6. Incident investigation process & 3.3 & 3.0 & 2.8 & 2.5 & 3.8 & 3.0 \\
E7 Investigation timeline & 2.6 & 2.1 & 2.4 & 2.2 & 4.0 & 2.6 \\
E8 What initiates/drives incident investigation & 3.4 & 2.8 & 2.8 & 2.3 & 3.2 & 2.9 \\
E9. Who investigates (investigation team) & 3.3 & 2.6 & 2.6 & 2.5 & 3.4 & 2.9 \\
E10. Data sources & 3.3 & 2.8 & 2.3 & 2.5 & 3.4 & 2.8 \\
E11. Data representation & 3.3 & 1.9 & 1.6 & 3.7 & 3.4 & 2.6 \\
E12. Data analysis & 3.4 & 2.6 & 2.4 & 2.5 & 3.2 & 2.8 \\
E13. Causes commonly identified & 3.4 & 2.6 & 2.3 & 2.7 & 3.0 & 2.8 \\
E14. Planning corrective measures & 2.4 & 1.8 & 1.5 & 1.3 & 2.4 & 1.9 \\
E15. Nature of corrective measures & 3.3 & 2.8 & 2.1 & 2.0 & 3.2 & 2.6 \\
E16. Review of report/ findings & 4.4 & 2.8 & 2.3 & 1.7 & 4.8 & 3.1 \\
E17. Follow-up of implemented corrective measures & 3.1 & 2.5 & 2.1 & 2.2 & 3.4 & 2.6 \\
E18. Extent of disseminating lessons & 4.2 & 2.9 & 2.6 & 2.5 & 4.4 & 3.2 \\
E19. Channels for disseminating lessons & 3.3 & 3.3 & 2.6 & 2.5 & 2.6 & 2.9 \\
E20. Use of post-investigation findings & 3.0 & 2.6 & 2.3 & 2.2 & 3.4 & 2.7 \\
E0. Overall investigation maturity score & 3.3 & 2.5 & 2.3 & 2.3 & 3.4 & 2.7 \\
Incidence rate (IR) & 0.12 & 0.2 & 0.2 & 0.3 & 0.8 & 0.2 \\
\hline
\end{tabular}

\subsection{Association between Maturity of Incident Investigation and Safety Performance Metric}

One-way ANOVA $(F(5,295)=14.84, p<0.01)$ indicated that there was statistically significant difference in the incidence rate of the mines. Results of a post hoc (Table 5) test showed that incidence rate of Mine A was significantly lower than that of B, C, D and the incidence rate of E was equally significantly lower than $B$ and D. Again, although the incidence rate of Mine $C$ was lower than $\mathrm{B}$ and D; B lower than D; and A lower than E, their means differences were not statistically significant (see Table 5). 


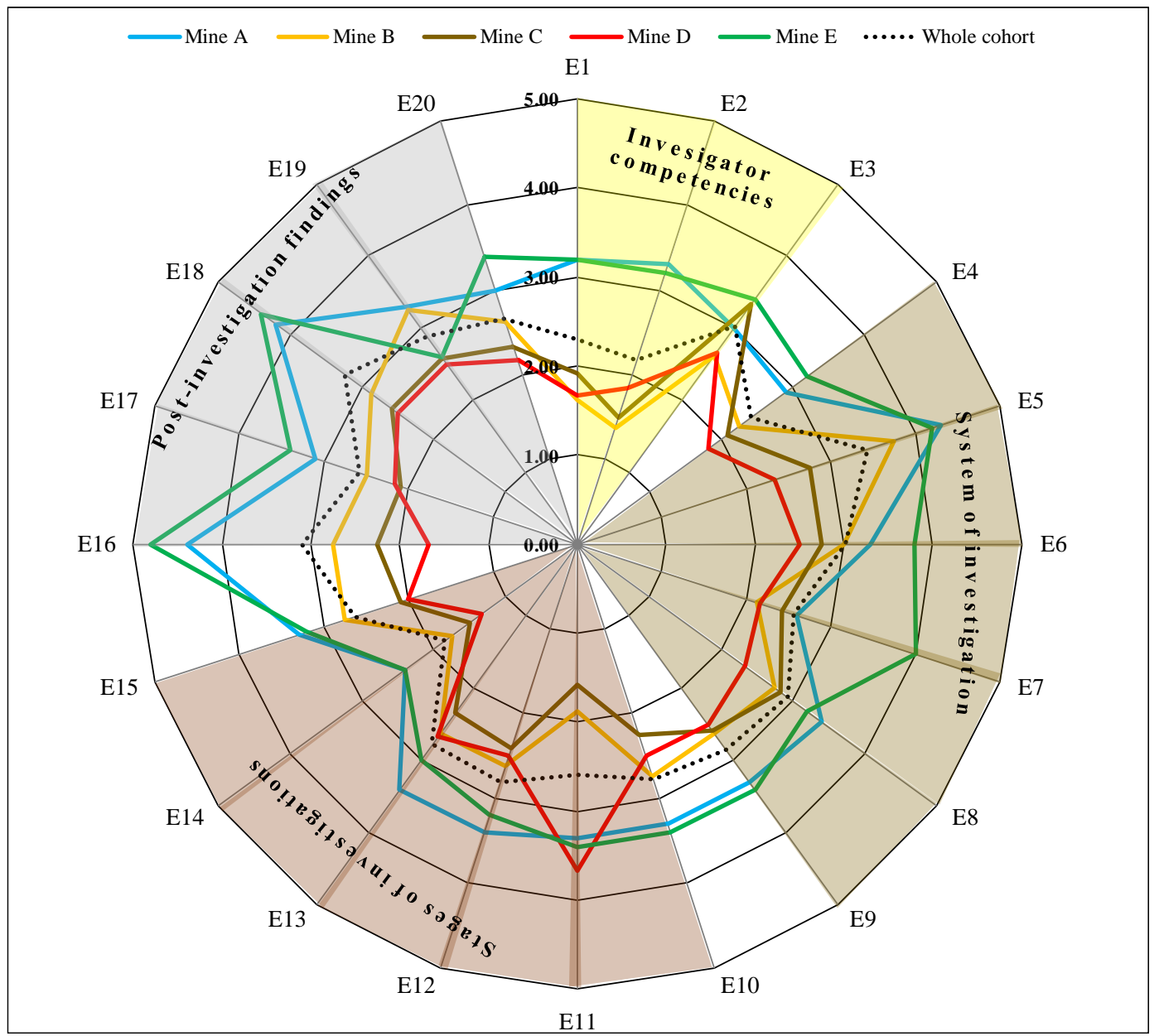

Figure 3. Spider diagram comparing means score of the investigation elements across the mines.

Table 5. Post hoc test of incidence rate across the mines (significant at $p<0.05$ ).

\begin{tabular}{cccc}
\hline Mine (i) & Mine $(\mathbf{j})$ & Mean Difference $(\mathbf{i}-\mathbf{j})$ & Significance \\
\hline A & B & -0.11 & 0.000 \\
& C & -0.10 & 0.000 \\
& D & -0.14 & 0.000 \\
B & E & -0.05 & 0.086 \\
& C & 0.01 & 0.998 \\
& D & -0.03 & 0.460 \\
C & E & 0.06 & 0.046 \\
& D & -0.04 & 0.280 \\
D & E & 0.05 & 0.102 \\
& E & 0.09 & 0.000 \\
\hline
\end{tabular}

The result of the ANOVA showed that the mines can generally be grouped into low $(\mathrm{A}, \mathrm{E})$ and high $(\mathrm{B}, \mathrm{C}, \mathrm{D})$ incidence rate mines. For two mines with relatively similar risks and hazards, the expectation is that the mine that better learns from its incidents through effective investigations will have fewer repeat accidents and low incidence rate than the mine whose incident investigations remain ineffective and, therefore, fails to learn from its past incidents. The predictive validity of the investigation maturity framework was therefore explored. 


\subsubsection{Averages as the Investigation Maturity Level of the Mines}

The results as shown in Section 3.3 indicated that response from Mines A and E consistently occupied the higher levels of investigation maturity for most of the elements, whereas responses from B, C and D consistently showed more characteristics of the lower level of investigation maturity for most of the elements. Additionally, the average investigation maturity scores (Table 4 and Figure 3) of Mines A and E consistently exceeded the average scores of B, C and D for most elements of the framework. Again, analysis of past incidents of the mines (Table 5) showed that the incidence rates of Mines A and E were significantly lower than the incidence rates of Mines B, C and D. Therefore, the maturity scores of the mines were categorised into two based on their incidence rate, that is, low incidence rate ( $\mathrm{A}$ and $\mathrm{E}$ ) and high incidence rate $(\mathrm{B}, \mathrm{C}$ and $\mathrm{D})$ mines. A sample independent $t$-test was run to determine the differences in the investigation maturity scores between high- and low-incidence rate mines. The results (Table 6) shows that all elements of the investigation maturity framework except elements E3 (professional networks to support investigations) and E19 (channel for disseminating lessons) were significantly higher at the low-incidence rate mines than at the high-incidence rate mines. Even for the elements (E3 and E19) that showed no statistically significant difference, the maturity scores for the low-incidence rate mines exceeded that of the high-incidence rate mines.

\subsubsection{Correlation between Incidence Rate and Means of Investigation Element Scores}

Figure 4 is a scatterplot showing the 5-year incidence rates and the mean of the average incident investigation maturity scores of the mines. This simple and straightforward analysis shows a relationship between the investigation maturity score and the incidence rate of the mines. The figure indicates that mines with high investigation maturity scores have lower incidence rates and mines with low investigation maturity scores have higher incidence rates.

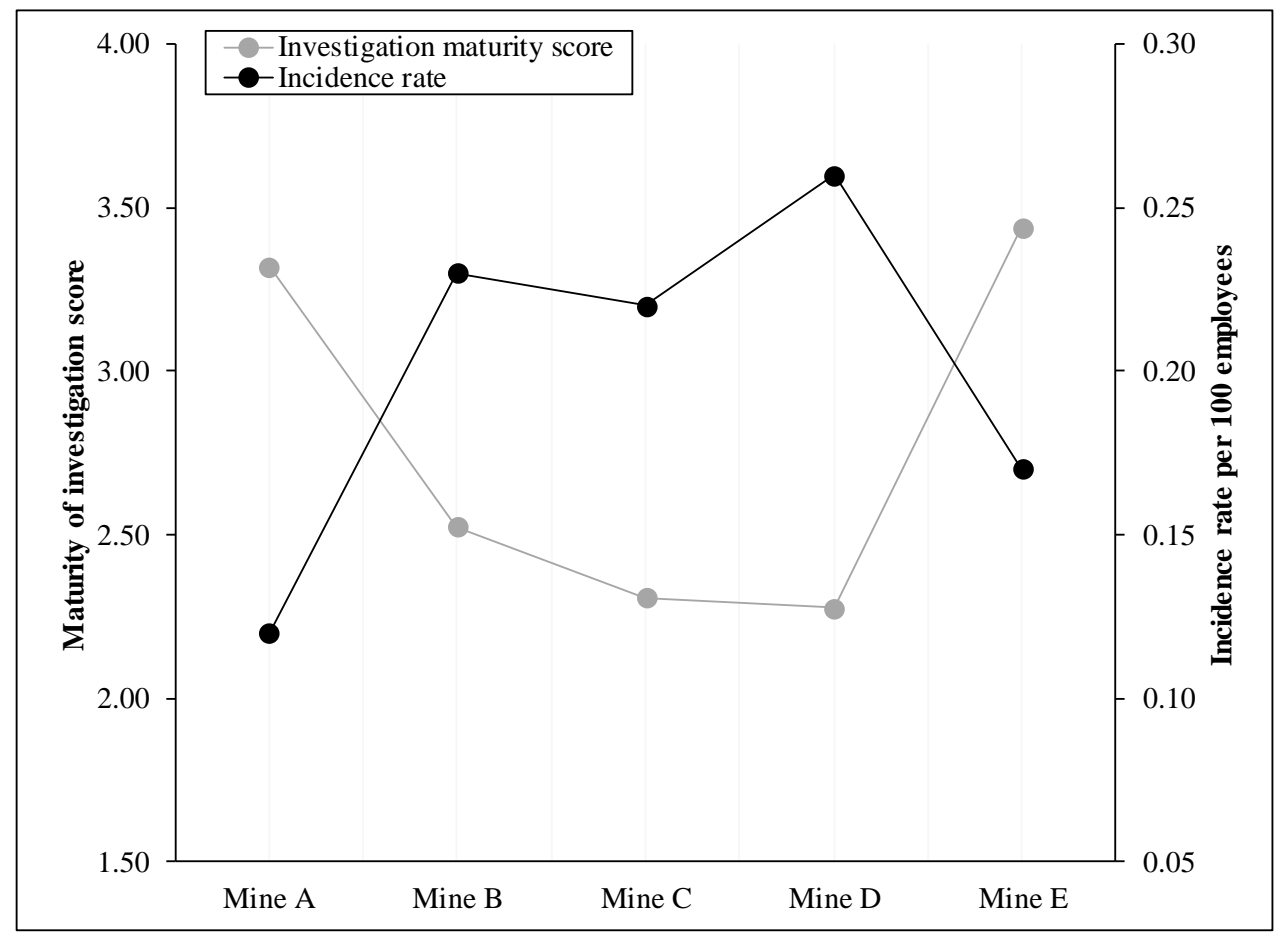

Figure 4. A plot of incidence rates and maturity of investigation scores of the mines. 
Table 6. $t$-Test results and mean scores of investigation elements in mines with low /high incidence rate (significant at $p<0.05)$.

\begin{tabular}{|c|c|c|c|}
\hline \multirow{2}{*}{ Element Name } & \multicolumn{2}{|c|}{ Mean of Maturity Framework Elements at Mines Where Incidence Rate Was } & \multirow{2}{*}{$t$-Test Results } \\
\hline & Low (A and $\mathrm{E})$ & High (B, C and D) & \\
\hline E1. Investigation training & 3.20 & 1.77 & $6.01, p=0.000$ \\
\hline E2. Knowledge of causation models/investigation methods & 3.27 & 1.54 & $7.56, p=0.000$ \\
\hline E3. Professional networks to support investigations & 3.13 & 2.96 & $0.67, p=0.509$ \\
\hline E4. Purpose of investigating incidents & 3.00 & 2.08 & $2.70, p=0.014$ \\
\hline E5. Incident types investigated & 4.27 & 2.96 & $5.64, p=0.000$ \\
\hline E6. Incident investigation process & 3.47 & 2.77 & $3.14, p=0.003$ \\
\hline E7 Investigation timeline & 3.07 & 2.27 & $3.43, p=0.001$ \\
\hline E8 What initiates/drives incident investigation & 3.33 & 2.69 & $3.44, p=0.001$ \\
\hline E9. Who investigates (investigation team) & 3.33 & 2.58 & $4.26, p=0.000$ \\
\hline E10. Data sources & 3.33 & 2.46 & $4.89, p=0.000$ \\
\hline E11. Data representation & 3.33 & 2.15 & $4.24, p=0.000$ \\
\hline E12. Data analysis & 3.33 & 2.50 & $4.67, p=0.000$ \\
\hline E13. Causes commonly identified & 3.27 & 2.50 & 4.37, $p=0.000$ \\
\hline E14. Planning corrective measures & 2.40 & 1.54 & $4.78, p=0.000$ \\
\hline E15. Nature of corrective measures & 3.27 & 2.27 & $5.13, p=0.000$ \\
\hline E16. Review of report/findings & 4.53 & 2.27 & $12.17, p=0.000$ \\
\hline E17. Follow-up of implemented corrective measures & 3.20 & 2.23 & $4.82, p=0.000$ \\
\hline E18. Extent of disseminating lessons & 4.27 & 2.65 & $9.45, p=0.000$ \\
\hline E19. Channels for disseminating lessons & 3.07 & 2.77 & $1.37, p=0.179$ \\
\hline E20. Use of post-investigation findings & 3.13 & 2.38 & $4.59, p=0.000$ \\
\hline E0. Overall investigation maturity score & 3.36 & 2.37 & $11.04, p=0.000$ \\
\hline
\end{tabular}


To explore further the relationship between the maturity of investigation and actual safety performance metric, the means of the averages of the investigation maturity scores of each of the 20 elements for each of the five mines as shown in Table 4 were correlated with the 5-year mean incidence rate of the mines through Spearman rank order correlation. The Spearman's correlation coefficient (r) presented in Table 7 reveals that all the elements of the framework and the global (overall investigation maturity) score correlated negatively with the incidence rates of the mines. The table further reveals that the correlation coefficients for all but five (E3, E10, E11, E17 and E19) elements were statistically significant at $p<0.05$. Elements E1 (investigation training), E8 (what initiates/drives investigation), E12 (data analysis) and E14 (planning corrective measures) had the highest correlation coefficient of $\mathrm{r} \geq-0.92$ at $p \leq 0.01$.

Table 7. Spearman's correlation ( $\mathrm{r}$ ) between incidence rate and incident investigation maturity score $(\mathrm{N}=5$, significant at $p<0.05)$.

\begin{tabular}{lcccc}
\hline \multicolumn{1}{c}{ Element Name } & Mean & SD & r & $p$-Value \\
\hline E1. Investigation training & 2.32 & 0.72 & -0.93 & 0.008 \\
E2. Knowledge of causation models/investigation methods & 2.23 & 0.84 & -0.83 & 0.042 \\
E3. Professional networks to support investigations & 3.01 & 0.32 & -0.54 & 0.266 \\
E4. Purpose of investigating incidents & 2.45 & 0.51 & -0.89 & 0.019 \\
E5. Incident types investigated & 3.46 & 0.79 & -0.83 & 0.042 \\
E6. Incident investigation process & 3.06 & 0.45 & -0.89 & 0.019 \\
E7. Investigation timeline & 2.64 & 0.69 & -0.89 & 0.019 \\
E8. What initiates/drives incident investigation & 2.91 & 0.37 & -1.00 & 0.000 \\
E9. Who investigates (investigation team) & 2.88 & 0.39 & -0.89 & 0.017 \\
E10. Data sources & 2.83 & 0.45 & -0.77 & 0.072 \\
E11. Data representation & 2.74 & 0.86 & -0.29 & 0.957 \\
E12. Data analysis & 2.82 & 0.40 & -0.92 & 0.008 \\
E13. Causes commonly identified & 2.80 & 0.37 & -0.83 & 0.042 \\
E14. Planning corrective measures & 1.87 & 0.45 & -0.93 & 0.008 \\
E15. Nature of corrective measures & 2.66 & 0.54 & -0.86 & 0.039 \\
E16. Review of report/findings & 3.16 & 1.22 & -0.89 & 0.019 \\
E17. Follow-up of implemented corrective measures & 2.64 & 0.52 & -0.77 & 0.072 \\
E18. Extent of disseminating lessons & 3.30 & 0.82 & -0.89 & 0.019 \\
E19. Channels for disseminating lessons & 2.85 & 0.35 & -0.60 & 0.208 \\
E20. Use of post-investigation findings & 2.70 & 0.45 & -0.89 & 0.019 \\
E0. Overall investigation maturity score & 2.77 & 0.50 & -0.89 & 0.019 \\
\hline
\end{tabular}

\section{Discussion}

When interpreting, reviewing and applying the results of this study, it is important to note that some limitations exist. The first is that although the face and content validity of the framework was assessed, the approach used was qualitative in nature and not quantitative. While the research participants understood the descriptions of the different levels of maturity and found the framework to be coherent, a quantitative assessment of the validity and reliability of the framework could further indicate how well the descriptions of the different maturity levels form statistically coherent and distinct groups. Therefore, statistical assessment of the structure, validity and reliability of the incident investigation framework needs further research. This will help determine any contradictions of the framework, such as whether descriptions from the more advanced levels (proactive and resilient) are perceived to be associated with the lower levels (basic and reactive). Secondly, the framework was applied on interview data collected from 41 investigators across five mines in Ghana. The narrow diversity of study sites and the relatively small sample size could limit the application of the framework and generalisation of the findings beyond those five mines and the GMI. Further research is required to determine the extent to which the framework is understandable and useful to other entities (different mines, industries and geographic areas). Another limitation is that since interviews supported the development of the framework, the framework may be limited by the 
mental models of the interviewees, which may or may not reflect the leading thinking (true proactive and resilient/regenerative practices) in this space. Further research involving subject matter experts would be required to test the validity of the upper ends of the scale. Again, the use of maturity levels could present some drawbacks. For instance, an organisation can look at each of the maturity levels as a target, making it their goal to achieve the next level up. This can present a danger of an organisation being fixated on achieving the next level up and neglecting the actual goal of continuously improving. Even when considering the above shortcomings, this study presents some interesting finding useful for improving the safety of the mines that will now be discussed.

\subsection{Incident Investigation Maturity Framework}

The study describes a framework for assessing the maturity of incident investigations. The dimensions and elements of the framework reflect the necessary aspects of theoretical and practical incident investigation and consistent with other safety-related maturity frameworks such as the safety culture maturity framework $[31,50]$. Both concrete and abstract aspects of incident investigation were considered. Tangible or concrete elements are aspects of an organisation's incident management processes that are visible to both outsiders and insiders, such as, the systems for organising investigations and the way in which investigations are formally planned and implemented, such as elements E5, E6, E7, E11 and E12. The abstract elements considered the perception of the workforce regarding less tangible/intangible aspects such as knowledge of causation models/investigation methods and what is considered the purpose of incident investigations in the mine.

The maturity model concept was also found suitable as it is widely accepted and applied within the mining industry in studying safety culture [19,43,44]. Employees of the participating mines found the final framework useful and understandable. Participants from the mines approved the dimension and elements of the framework as well as the five maturity levels. Future research that uses large data and focuses on differences in responses of different groups within the same organisation, such as between frontline managers and top managers would be invaluable. This will allow for the identification of differences in perception of the effectiveness of investigation between those groups.

\subsection{Different Levels of Incident Investigation Maturity}

By applying the framework to interview data, it was observed that the mines had different levels of investigation effectiveness. Although most of the mines did not show characteristics of the two extremes of investigation advancements, the study revealed the existence of different incident investigation maturity levels across the mines. By applying the concept of different maturity levels, this study shows weak and strong areas across the mines with respect to how investigation are conducted. By revealing such strengths and deficiencies, the study provides a basis for developing improvement strategies specific to those weak areas. Across the mines, the elements focusing on the latter stage of investigation, the competencies of the investigators, and the use of post-investigation findings had the lowest scores. In particular, the planning of corrective measures, the investigation training investigators had received and their knowledge of causation models, and investigation methods showed more characteristics of the lower level of maturity and fewer/no characteristics of the advanced levels. Conversely, the elements focusing on the type of incident investigated and how they are investigated and the channels and extent of disseminating lessons exhibited more characteristics of the upper levels and fewer characteristics of the less advanced levels of maturity across the mines. This illustrates that within a specific organisation, there are aspects where the maturity of incidents investigations could be more developed than in other aspects. This could also mean that actions to improve incident investigations may not exert the same effect in all areas.

The findings of the research further give an indication of areas that is of focus in the mines and identify areas warranting greater focus. For instance, the elements focusing on how investigations are organised at the mines and the distribution of lessons had higher scores than elements focusing on the planning of remedial measures and the training and knowledge of investigators. The less 
focus on the competencies of investigators deserves further attention to improve safety. Within the literature, it has been recognised that the competencies of investigators affect incident analyses and what is acceptable as an accident causal factor [12,51]. Moreover, Lundberg, Rollenhagen [11] observed that the causes often identified during investigations reflect the causation model underlying the investigation method applied. If improvement is to be achieved in how organisations investigate incidents, the knowledge, competencies and expertise of those undertaking the investigation remain paramount. The more knowledgeable the investigators become through training on causation models, the better they can analyse incidents to find latent causes and develop effective remedial measures to advance safety. Similarly, the low scores of element E14 (planning remedial measures) across the mines deserves further attention. This is because, although the identification of causes remains vital, it is only when improvement measures are effectively planned and implemented that the much desired safety improvement can be achieved.

The individual mines were also separated into those that exhibited characteristics of the more advanced stages of investigation maturity and those that showed characteristics of the lower stages. The scores at Mines A and E were consistently higher than the scores at Mines B, C and D and several reasons could have accounted for this. Interviews at A revealed that the mine had previously undertaken a safety transformation agenda, where safety was to be considered at the early stages of project planning. This safety programme was necessitated by analyses of previous accidents, which showed that "human error" was often identified as the cause of accidents, and accidents kept recurring because of the dominance of the blame culture. Management invested to shift the paradigm from a blame culture to a learning culture where accidents are thoroughly analysed with a systemic view. The interviewees acknowledged the value of that investment in their incident investigations, citing several examples of previous investigations where individual would have been punished under the old culture. However, under the new emerging culture, they consider learning paramount, focusing more on blunt-end causes in contrast to the proximate sharp-end causes [10]. Field interaction at Mine A revealed that investigation training is skill-based and sometimes tailored to individual needs. An investigator's involvement in an investigation was often based on the level of training received and those with the greatest expertise in the field of practice and knowledge of causation models and investigation methods led investigations, particularly the high-level events. Additionally, both Mines $\mathrm{A}$ and $\mathrm{E}$ had a strong focus on classifying an incident and selecting a level of investigation based on both the actual and potential consequences of the incident. Moreover, an organisational learning team with participation from sister mines and the corporate office was employed in investigating high-level events. At both mines, the interviewees indicated that after completing an investigation, it is reviewed by a learning team consisting of a wide range of employees both in and outside the mine before recommendations are implemented. The participants stated that the review offers much value as there is often exchange of ideas among the sites, which ensure that effective remedial measures are implemented. These initiatives were not occurring at the other mines. Therefore, there is potential for the less matured mines to learn from the matured mines.

\subsection{Association between Maturity of Incident Investigation and Safety Performance Metrics}

The five mines had significantly different safety performance metrics. This was proven by one-way analysis of variance conducted on the incidence rates of the mines. Through a pairwise comparison test, low-incidence rate mines were clearly distinguished from high-incidence rate mines. For example, the incidence rates of Mines A and E were significantly lower than Mines B, C and D. Although the mines have similar characteristics such as their ownership, several factors could have contributed to the differences in their incidence rates. One contributing factor could be the maturity of incident investigations and how effective the mines learn from past incidents to improve safety. An important objective of this study was to investigate the predictive validity of the framework by exploring whether the elements of the framework correlated with an actual safety performance metric of mines. Consistently, the low-incidence rate mines had the highest maturity of investigation scores 
and the high-incidence rate mines had a lowest maturity of investigation scores. Statistical analyses proved that the maturity of investigation scores of the low-incidence rate mines were significantly higher than the scores of the high-incidence rate mines. This suggest that organisations with a matured incident investigation culture stand a better chance of improving their safety performance, and a more matured investigations could be a factor in reducing incidents.

Correlation analysis revealed that the investigation training of the investigators, how data is analysed and what drives investigations had the strongest correlation with the incidence rate of the mines. The planning of remedial measures and review of investigation findings also correlated strongly with the incidence rate. The strongly correlated elements could be an indication of areas deserving greater focus. For example, improving the knowledge of investigators through skill-based training tailored to individual needs could contribute to advancing safety. This research does not only present valuable findings for advancing the safety of the mines, it also provides direction for future research, particularly the elements that correlated strongly with the safety performance metric. For example, an investigation of the competency requirements of incident investigators remains vital; such a study would support the development of competency-based training for investigators. This is because competency-based training has been found to be more useful, productive and to facilitate individual development in contrast to training based on learning job skills [52].

\subsection{Implications for Practice}

The main outcome of this study is the incident investigation maturity framework, which is a method for assessing the maturity/effectiveness of four aspects of practical incident investigations. The framework worked well when applied on interview data collected from five different mines, even though the mines had different investigation processes and requirements. Additionally, investigators recognised the framework to be valid, coherent, consistent and useful when they were contacted to review the framework. This second contact with the investigators was useful in refining the initial framework. The framework could be an effective self-assessment method for evaluating the effectiveness/maturity of an organisation's incident investigations to reveal weak areas for improvement. The application of the framework yielded good results for each of the mines. However, as the responses vary from respondent to respondent, a larger number of responses is necessary to be able to draw conclusions about the maturity of investigations. The results of applying the framework in terms of numbers for the maturity level of the various elements would be suitable to use for correlation with other safety performance metrics.

\section{Conclusions}

This paper describes the development of an incident investigation maturity framework and the application of the framework to five large-scale mines operating in Ghana to determine the position of the mines on the framework. The research also sought to examine the relationship between the different levels of investigation maturities and actual safety performance metric. Therefore, the research contributions are twofold. First, the research extends upon the maturity framework theory and knowledge. Second, the research demonstrates a novel application of the maturity framework to mines in Ghana.

The results from the Ghanaian mines highlighted that the framework's elements focusing on investigator competencies showed more characteristics of the lower stage of maturity and fewer characteristics of the higher stage. Furthermore, the elements of the latter stage of investigations were less advanced than the elements of the earlier stages of investigations, particularly the planning of remedial measures. This gives broad indications of deficient areas deserving greater focus. Across the mines, low-incidence rate mines had higher maturity scores and high-incidence rate mines had lower maturity scores. Statistical tests proved that these differences were significant, suggesting the existence of a negative correlation between the maturity of incident investigation and incidence rate. In addition, the elements of the framework correlated differently with the incidence rate and 
the strongly correlated elements included investigator training, data analysis and planning remedial measures. Finally, although participants recognised the framework to be useful and the descriptions of the different maturity levels was considered coherent and accurate, statistical analysis of the structure, validity and reliability, and potential application of the framework could strengthen its theoretical foundation. Again, although the research highlights the potential of the maturity framework for identifying improvements in the incident investigation process that if implemented can lead to better safety performance, further work is required to determine the generalisability of the framework.

Author Contributions: E.S. conceived the research idea, collected and analysed the data and composed the initial manuscript. C.B., D.C. and M.E.H. directed the research and provided ongoing reviews, critical feedbacks and edits of the manuscript.

Funding: The Australian Government through the Research Training Program Scholarship and the University of Queensland through the UQ Centennial Scholarship supported this research financially.

Acknowledgments: We acknowledge the assistance of the Inspectorate Division of the Minerals Commission of Ghana, the five mines and individual interview respondents whose time, resources and information were vital to the research. We are also grateful to the Minerals Industry Safety and Health Centre and the Sustainable Minerals Institute, at the University of Queensland for their support. Finally, we are grateful to Jill Harris for her advice on the appropriateness of statistical analyses.

Conflicts of Interest: The authors declare no conflict of interest. 


\section{Appendix A. Framework for Assessing Maturity of Investigator Competencies}

\begin{tabular}{|c|c|c|c|c|c|c|}
\hline \multicolumn{2}{|c|}{ Component } & \multicolumn{5}{|c|}{ Maturity Level } \\
\hline Dimension & Element & 1-Basic & 2-Reactive & 3-Compliant & 4-Proactive & 5-Resilient \\
\hline \multirow{3}{*}{$\begin{array}{l}\text { Investigator } \\
\text { competencies }\end{array}$} & $\begin{array}{l}\text { Investigation training } \\
\text { (E1) }\end{array}$ & $\begin{array}{l}\text { No formal training is } \\
\text { given, investigators are } \\
\text { on their own to skill-up }\end{array}$ & $\begin{array}{l}\text { Basic formal investigation } \\
\text { training (including how } \\
\text { to conduct interviews, } \\
\text { data collection, } \\
\text { reporting findings) }\end{array}$ & $\begin{array}{l}\text { Investigation training } \\
\text { is given, including } \\
\text { general knowledge } \\
\text { and investigation } \\
\text { method used at site }\end{array}$ & $\begin{array}{l}\text { Skill-based investigation } \\
\text { training and development } \\
\text { is given, including how to } \\
\text { identify and manage } \\
\text { motivational and } \\
\text { cognitive biases }\end{array}$ & $\begin{array}{l}\text { Regular investigation training } \\
\text { and development tailored to } \\
\text { individual needs identified } \\
\text { through evaluation, with } \\
\text { ongoing coaching, including } \\
\text { how to identify and manage } \\
\text { motivational and } \\
\text { cognitive biases }\end{array}$ \\
\hline & $\begin{array}{c}\text { Knowledge of } \\
\text { causation } \\
\text { models/investigation } \\
\text { methods } \\
\text { (E2) } \\
\end{array}$ & $\begin{array}{l}\text { No knowledge of } \\
\text { academic causation } \\
\text { models and } \\
\text { investigation methods }\end{array}$ & $\begin{array}{c}\text { Knowledge of } \\
\text { investigation method } \\
\text { used at site, but lacks } \\
\text { knowledge of underlying } \\
\text { causation model }\end{array}$ & $\begin{array}{l}\text { Knowledge of } \\
\text { investigation method } \\
\text { and underlying } \\
\text { causation model in } \\
\text { use at site }\end{array}$ & $\begin{array}{c}\text { Exposed to a variety of } \\
\text { models and methods, } \\
\text { however, understands the } \\
\text { model/method used at the } \\
\text { site than the others }\end{array}$ & $\begin{array}{l}\text { In-depth knowledge of several } \\
\text { models and methods, } \\
\text { recognises their differences and } \\
\text { uses them appropriately }\end{array}$ \\
\hline & $\begin{array}{l}\text { Professional networks } \\
\text { to support } \\
\text { investigations } \\
\text { (E3) }\end{array}$ & $\begin{array}{l}\text { Investigator does not } \\
\text { belong to any } \\
\text { professional network to } \\
\text { support } \\
\text { investigation practices }\end{array}$ & $\begin{array}{l}\text { Investigator is part of a } \\
\text { local investigators' } \\
\text { network, however } \\
\text { knowledge-sharing is ad } \\
\text { hoc limiting } \\
\text { its effectiveness }\end{array}$ & $\begin{array}{l}\text { Investigator is part of } \\
\text { a proactive local } \\
\text { investigators network } \\
\text { where there is regular } \\
\text { knowledge transfer }\end{array}$ & $\begin{array}{l}\text { Investigator participate in } \\
\text { professional networks both } \\
\text { local and outside his/her } \\
\text { own organisation to learn } \\
\text { from other sites/domain }\end{array}$ & $\begin{array}{l}\text { Investigator regularly } \\
\text { participates in several } \\
\text { investigators networks locally } \\
\text { and outside organisation to } \\
\text { continuously learn from others } \\
\text { and improve competencies }\end{array}$ \\
\hline
\end{tabular}




\section{Appendix B. Framework for Assessing Maturity of the System of Investigations}

\begin{tabular}{|c|c|c|c|c|c|c|}
\hline \multicolumn{2}{|c|}{ Component } & \multicolumn{5}{|c|}{ Maturity Level } \\
\hline Dimension & Element & 1-Basic & 2-Reactive & 3-Compliant & 4-Proactive & 5-Resilient \\
\hline \multirow{6}{*}{$\begin{array}{l}\text { System of } \\
\text { investigation }\end{array}$} & $\begin{array}{l}\text { Purpose of } \\
\text { investigating } \\
\text { incidents } \\
\text { (E4) }\end{array}$ & $\begin{array}{l}\text { Compliance with } \\
\text { regulatory requirement, } \\
\text { to find and punish } \\
\text { the culprits }\end{array}$ & $\begin{array}{l}\text { Compliance but to find } \\
\text { the causes of the incident } \\
\text { and recommend } \\
\text { corrective measures }\end{array}$ & $\begin{array}{l}\text { To find systemic } \\
\text { cause to the incident } \\
\text { and prevent } \\
\text { same/similar events }\end{array}$ & $\begin{array}{l}\text { Incident are investigated to } \\
\text { learn: to identify, share, } \\
\text { store, preserve and embed } \\
\text { lessons to prevent } \\
\text { future events }\end{array}$ & $\begin{array}{l}\text { Investigation is an accepted, } \\
\text { important part of the work } \\
\text { process, its purpose is to } \\
\text { embed lessons into the } \\
\text { work process for } \\
\text { continuous improvements }\end{array}$ \\
\hline & $\begin{array}{l}\text { Incident types } \\
\text { investigated } \\
\text { (E5) }\end{array}$ & $\begin{array}{l}\text { Only accident with } \\
\text { specific well-defined (by } \\
\text { law or } \\
\text { regulation) outcomes } \\
\text { are investigated }\end{array}$ & $\begin{array}{c}\text { Investigations are done } \\
\text { on only accidents with } \\
\text { serious outcomes such as } \\
\text { fatalities and } \\
\text { serious injury }\end{array}$ & $\begin{array}{c}\text { Investigations are } \\
\text { done on accident with } \\
\text { actual outcome, both } \\
\text { serious and } \\
\text { non-serious outcomes }\end{array}$ & $\begin{array}{l}\text { Investigations are done on } \\
\text { accidents and incidents (no } \\
\text { losses but significant } \\
\text { potential for losses) }\end{array}$ & $\begin{array}{l}\text { All incidents are effectively } \\
\text { investigated with a level of } \\
\text { investigation that is selected } \\
\text { based on the potential rather } \\
\text { than actual outcome }\end{array}$ \\
\hline & $\begin{array}{l}\text { Incident investigation } \\
\text { process } \\
\text { (E6) }\end{array}$ & $\begin{array}{l}\text { No standardised } \\
\text { investigation process } \\
\text { exist, investigation is } \\
\text { ad hoc }\end{array}$ & $\begin{array}{l}\text { Processes governing } \\
\text { investigations are } \\
\text { formalised, published } \\
\text { and enforced }\end{array}$ & $\begin{array}{l}\text { Investigation process } \\
\text { is aligned to best } \\
\text { practice guidelines for } \\
\text { investigation }\end{array}$ & $\begin{array}{l}\text { Process for investigations } \\
\text { are formalised and } \\
\text { reviewed for continued } \\
\text { applicability }\end{array}$ & $\begin{array}{l}\text { Investigation process is } \\
\text { continuously reviewed for } \\
\text { improvement opportunities }\end{array}$ \\
\hline & $\begin{array}{l}\text { Investigation timeline } \\
\text { (E7) }\end{array}$ & No timeline is specified & $\begin{array}{l}\text { The same timeline is } \\
\text { specified, but for only } \\
\text { serious accident with } \\
\text { mandatory investigation }\end{array}$ & $\begin{array}{l}\text { Different timelines } \\
\text { are specified for } \\
\text { serious incidents, all } \\
\text { other incidents are } \\
\text { investigated } \\
\text { following the } \\
\text { same timeline }\end{array}$ & $\begin{array}{l}\text { Different timelines are } \\
\text { specified for different } \\
\text { incident based on } \\
\text { actual outcome }\end{array}$ & $\begin{array}{l}\text { Different timeline exist and the } \\
\text { selection is based on the } \\
\text { potential and actual outcome } \\
\text { of the incident }\end{array}$ \\
\hline & $\begin{array}{l}\text { What initiates/drives } \\
\text { an incident } \\
\text { investigation } \\
\text { (E8) }\end{array}$ & $\begin{array}{l}\text { Investigation occurs } \\
\text { when required by } \\
\text { insurance and/or } \\
\text { regulatory requirements }\end{array}$ & $\begin{array}{l}\text { Investigation of accidents } \\
\text { occurs when there is an } \\
\text { injury or loss as required } \\
\text { by the site or company }\end{array}$ & $\begin{array}{l}\text { Investigations occurs } \\
\text { because management } \\
\text { see the value and } \\
\text { appreciate it effect on } \\
\text { safety improvement }\end{array}$ & $\begin{array}{l}\text { Investigation is usually } \\
\text { driven by frontline leaders } \\
\text { because they see and } \\
\text { appreciate its value }\end{array}$ & $\begin{array}{l}\text { Investigation is an accepted } \\
\text { and important part of the } \\
\text { work process }\end{array}$ \\
\hline & $\begin{array}{l}\text { Who investigates } \\
\text { (investigation team) } \\
\text { (E9) }\end{array}$ & $\begin{array}{l}\text { Victim/witness } \\
\text { completes accident } \\
\text { report, investigations are } \\
\text { done by management }\end{array}$ & $\begin{array}{l}\text { Investigation is } \\
\text { conducted by the safety } \\
\text { department, with } \\
\text { employee } \\
\text { involvement for } \\
\text { high-consequence events }\end{array}$ & $\begin{array}{l}\text { Investigation is done } \\
\text { by team including } \\
\text { managers and } \\
\text { employees and led by } \\
\text { safety department }\end{array}$ & $\begin{array}{l}\text { Multidisciplinary team } \\
\text { investigates, including } \\
\text { managers and employees } \\
\text { trained in accident analysis }\end{array}$ & $\begin{array}{l}\text { Organisational learning teams } \\
\text { include a cross-section of } \\
\text { employees and managers and } \\
\text { is led by those with the greatest } \\
\text { expertise of the practice }\end{array}$ \\
\hline
\end{tabular}


Appendix C. Framework for Assessing Maturity of the Stages of Investigations

\begin{tabular}{|c|c|c|c|c|c|c|}
\hline \multicolumn{2}{|c|}{ Component } & \multicolumn{5}{|c|}{ Maturity Level } \\
\hline Dimension & Element & 1-Basic & 2-Reactive & 3-Compliant & 4-Proactive & 5-Resilient \\
\hline \multirow{6}{*}{$\begin{array}{l}\text { Stage of } \\
\text { investigation }\end{array}$} & $\begin{array}{l}\text { Data sources } \\
\quad \text { (E10) }\end{array}$ & $\begin{array}{l}\text { There is a focus on the } \\
\text { workers involved (e.g., } \\
\text { drug and alcohol testing, } \\
\text { training records) }\end{array}$ & $\begin{array}{l}\text { There is focus on the } \\
\text { accident scene and } \\
\text { adjoining areas }\end{array}$ & $\begin{array}{l}\text { There is a focus on all } \\
\text { data directly related to } \\
\text { the incident, including } \\
\text { maintenance records, } \\
\text { work environment }\end{array}$ & $\begin{array}{l}\text { A wide range of data is } \\
\text { used including those not } \\
\text { directly related to the } \\
\text { incident, however, focus is } \\
\text { on the organisation and } \\
\text { not outside }\end{array}$ & $\begin{array}{l}\text { A wide range of data is used, } \\
\text { including those from outside and } \\
\text { other safety activities such as audits, } \\
\text { risk assessment, } \\
\text { previous investigations }\end{array}$ \\
\hline & $\begin{array}{l}\text { Data representation } \\
\text { (E11) }\end{array}$ & $\begin{array}{l}\text { No specific requirement } \\
\text { for representing the } \\
\text { accident scenario }\end{array}$ & $\begin{array}{l}\text { General description of } \\
\text { the accident with no } \\
\text { sequential order }\end{array}$ & $\begin{array}{l}\text { Sequential description of } \\
\text { the accident scenario }\end{array}$ & $\begin{array}{l}\text { Timeline charts are } \\
\text { used to represent the } \\
\text { incident scenario }\end{array}$ & $\begin{array}{l}\text { Incident information is summarised } \\
\text { using timeline charts to identify } \\
\text { information gaps and effective } \\
\text { communication among the team }\end{array}$ \\
\hline & $\begin{array}{l}\text { Data analysis } \\
\quad \text { (E12) }\end{array}$ & $\begin{array}{l}\text { Analysis is very } \\
\text { superficial, not going } \\
\text { beyond legal } \\
\text { requirements }\end{array}$ & $\begin{array}{l}\text { Analysis is usually } \\
\text { restricted to the level of } \\
\text { frontline workers, where } \\
\text { the accident occurred }\end{array}$ & $\begin{array}{l}\text { Analysis includes aspects } \\
\text { other than where the } \\
\text { accident occurred, such } \\
\text { as upstream decisions } \\
\text { about work, training, } \\
\text { work environment }\end{array}$ & $\begin{array}{l}\text { Analysis is systematic in } \\
\text { nature considering human } \\
\text { factors and management } \\
\text { systems issues, involving } \\
\text { root cause analysis }\end{array}$ & $\begin{array}{l}\text { Analysis is guided by the system } \\
\text { complexity and is therefore open } \\
\text { incorporating all levels of a } \\
\text { sociotechnical system with a focus } \\
\text { on control effectiveness and } \\
\text { emergent behaviour }\end{array}$ \\
\hline & $\begin{array}{l}\text { Causes commonly } \\
\text { identified } \\
\text { (E13) }\end{array}$ & $\begin{array}{l}\text { Many accidents are seen } \\
\text { as unavoidable (act of } \\
\text { God) and as part of } \\
\text { the job }\end{array}$ & $\begin{array}{l}\text { Accidents are seen as } \\
\text { preventable and manager } \\
\text { perceive that majority of } \\
\text { accidents are solely } \\
\text { caused by the unsafe } \\
\text { behaviour of } \\
\text { frontline staff }\end{array}$ & $\begin{array}{l}\text { Manager recognise that a } \\
\text { wide range of factors } \\
\text { cause accidents and the } \\
\text { root cause often } \\
\text { originate from } \\
\text { management decisions }\end{array}$ & $\begin{array}{l}\text { Managers and frontline } \\
\text { staff recognise that a wide } \\
\text { range of factors cause } \\
\text { accidents and the root } \\
\text { causes are likely to } \\
\text { come back to } \\
\text { management decisions }\end{array}$ & $\begin{array}{l}\text { Senior leaders and all employees } \\
\text { recognise that they are dealing with } \\
\text { a complex system within which a } \\
\text { wide range of factors cause accidents } \\
\text { and the root causes are likely to } \\
\text { come back to management decisions, } \\
\text { workplace design, organization } \\
\text { systems, absent/failed controls }\end{array}$ \\
\hline & $\begin{array}{l}\text { Planning corrective } \\
\text { measures } \\
\text { (E14) }\end{array}$ & $\begin{array}{l}\text { Corrective measures are } \\
\text { noted to re-rank risk with } \\
\text { no discussion }\end{array}$ & $\begin{array}{l}\text { A formal process is } \\
\text { applied to discuss } \\
\text { corrective measures and } \\
\text { their effectiveness }\end{array}$ & $\begin{array}{l}\text { Critical corrective } \\
\text { measures and their } \\
\text { effectiveness are } \\
\text { identified following a } \\
\text { formal process }\end{array}$ & $\begin{array}{l}\text { Critical corrective measures } \\
\text { are identified with } \\
\text { objectives and performance } \\
\text { requirements }\end{array}$ & $\begin{array}{l}\text { Identified critical corrective } \\
\text { measures include information for } \\
\text { integration into the work process }\end{array}$ \\
\hline & $\begin{array}{l}\text { Nature of corrective } \\
\text { measures } \\
\text { (E15) }\end{array}$ & $\begin{array}{l}\text { Corrective measures } \\
\text { mostly focus on those } \\
\text { (e.g., their behaviour, } \\
\text { competencies) involved } \\
\text { in the accident, such as } \\
\text { training, induction, } \\
\text { punishment, etc. }\end{array}$ & $\begin{array}{l}\text { Corrective measures are } \\
\text { mostly administrative in } \\
\text { nature, such as } \\
\text { procedures, permit to } \\
\text { work, etc., focusing } \\
\text { largely on the task or } \\
\text { incident location }\end{array}$ & $\begin{array}{l}\text { Corrective measure } \\
\text { include both human } \\
\text { actions and objects } \\
\text { (engineering), however, } \\
\text { but mostly rather } \\
\text { local view }\end{array}$ & $\begin{array}{l}\text { A wide range of corrective } \\
\text { measures, including } \\
\text { human actions and objects } \\
\text { with a broader view other } \\
\text { the specific event } \\
\text { under investigation }\end{array}$ & $\begin{array}{l}\text { A wide range of measures with a } \\
\text { broader view, including forces } \\
\text { outside the organisation (e.g., } \\
\text { regulator, government authorities) } \\
\text { focusing on developing new things } \\
\text { to eliminate/replace the hazard }\end{array}$ \\
\hline
\end{tabular}




\section{Appendix D. Framework for Assessing Maturity of the Use of Post-Investigation Findings}

\begin{tabular}{|c|c|c|c|c|c|c|}
\hline \multicolumn{2}{|c|}{ Component } & \multicolumn{5}{|c|}{ Maturity Level } \\
\hline Dimension & Element & 1-Basic & 2-Reactive & 3-Compliant & 4-Proactive & 5-Resilient \\
\hline \multirow{5}{*}{$\begin{array}{l}\text { Post-investigation } \\
\text { findings }\end{array}$} & $\begin{array}{l}\text { Review of } \\
\text { report/findings } \\
\text { (E16) }\end{array}$ & No review of findings & $\begin{array}{l}\text { Review is done by the } \\
\text { team completing the } \\
\text { investigation, and } \\
\text { sometimes by the } \\
\text { manager of the } \\
\text { affected area }\end{array}$ & $\begin{array}{l}\text { Review is done by team } \\
\text { including the manager } \\
\text { and employees of the } \\
\text { affected area and the } \\
\text { safety department }\end{array}$ & $\begin{array}{l}\text { Multidisciplinary team } \\
\text { from the site, including } \\
\text { managers and employees } \\
\text { review the } \\
\text { investigation findings }\end{array}$ & $\begin{array}{l}\text { Organisational learning teams } \\
\text { including a cross section of } \\
\text { employees and managers } \\
\text { within and outside the site } \\
\text { review findings and learn } \\
\text { from others }\end{array}$ \\
\hline & $\begin{array}{l}\text { Follow-up of } \\
\text { implemented } \\
\text { corrective measures } \\
\quad(\text { E17) }\end{array}$ & $\begin{array}{l}\text { There is limited, } \\
\text { if any follow-up }\end{array}$ & $\begin{array}{l}\text { There are some informal } \\
\text { or sporadic follow-ups }\end{array}$ & $\begin{array}{l}\text { Some follow-up is } \\
\text { defined and done for } \\
\text { specific actions, the } \\
\text { purpose is to ascertain } \\
\text { implementation }\end{array}$ & $\begin{array}{l}\text { All critical corrective } \\
\text { measures are systematically } \\
\text { verified and their } \\
\text { status reported }\end{array}$ & $\begin{array}{l}\text { Verifying the work process } \\
\text { includes critical } \\
\text { corrective measures }\end{array}$ \\
\hline & $\begin{array}{c}\text { Extent of } \\
\text { disseminating lessons } \\
\text { (E18) }\end{array}$ & $\begin{array}{l}\text { Lessons are often not } \\
\text { shared, only those of } \\
\text { major accidents are } \\
\text { sometime shared. }\end{array}$ & $\begin{array}{l}\text { Lessons are } \\
\text { communicated to the } \\
\text { safety department and } \\
\text { senior management }\end{array}$ & $\begin{array}{l}\text { Specific and related } \\
\text { portions of some } \\
\text { investigation findings } \\
\text { are shared with the line } \\
\text { manager at the location } \\
\text { where the } \\
\text { incident occurred }\end{array}$ & $\begin{array}{l}\text { Lessons are communicated } \\
\text { to all employees of the } \\
\text { sector/department where } \\
\text { the incident occurred to } \\
\text { ensure they learn from } \\
\text { the incident }\end{array}$ & $\begin{array}{l}\text { Lessons are broadly } \\
\text { disseminated throughout the } \\
\text { organisation and sister } \\
\text { organisations to ensure that } \\
\text { every employee learns from } \\
\text { all incidents }\end{array}$ \\
\hline & $\begin{array}{l}\text { Channels for } \\
\text { disseminating lessons } \\
\text { (E19) }\end{array}$ & $\begin{array}{l}\text { Lessons are shared either } \\
\text { electronically (emails) or } \\
\text { on notice boards }\end{array}$ & $\begin{array}{l}\text { Lessons are disseminated } \\
\text { through hard copy } \\
\text { (notice boards) and } \\
\text { electronically (emails) }\end{array}$ & $\begin{array}{c}\text { Lessons are } \\
\text { disseminated through } \\
\text { hard copy and } \\
\text { electronically, including } \\
\text { regular safety news, } \\
\text { improvement suggestion } \\
\text { and safety meeting }\end{array}$ & $\begin{array}{l}\text { Electronic and hard copy } \\
\text { suggestion systems that } \\
\text { provides feedback is used } \\
\text { as well as regular meeting } \\
\text { to facilitate open dialogue }\end{array}$ & $\begin{array}{l}\text { Extensive use of interactive } \\
\text { systems, innovative and } \\
\text { improvement groups. } \\
\text { Employees are engaged at } \\
\text { regular forums both } \\
\text { electronically and face to face, } \\
\text { both formally and informally }\end{array}$ \\
\hline & $\begin{array}{l}\text { Use of } \\
\text { post-investigation } \\
\text { findings } \\
\text { (E20) }\end{array}$ & $\begin{array}{l}\text { There is limited if any use } \\
\text { of post-investigation } \\
\text { findings }\end{array}$ & $\begin{array}{l}\text { Use to correct major } \\
\text { deficiencies related to } \\
\text { the accident }\end{array}$ & $\begin{array}{l}\text { Use to correct most } \\
\text { deficiencies related to } \\
\text { the accident }\end{array}$ & $\begin{array}{l}\text { Use to identify general } \\
\text { weakness in the risk } \\
\text { management system and } \\
\text { correct problems unrelated } \\
\text { to the accident }\end{array}$ & $\begin{array}{l}\text { Uncovering past incidents to } \\
\text { provide insights into } \\
\text { improving learning and overall } \\
\text { safety. Lessons are integrated } \\
\text { into the work process }\end{array}$ \\
\hline
\end{tabular}




\section{References}

1. Akselsson, R.; Jacobsson, A.; Bötjesson, M.; Ek, Å.; Enander, A. Efficient and effective learning for safety from incidents. Work 2012, 41, 3216-3222. [PubMed]

2. Jacobsson, A.; Ek, ̊.; Akselsson, R. Learning from incidents-A method for assessing the effectiveness of the learning cycle. J. Loss Prev. Process Ind. 2012, 25, 561-570. [CrossRef]

3. Lukic, D.; Littlejohn, A.; Margaryan, A. A framework for learning from incidents in the workplace. Saf. Sci. 2012, 50, 950-957. [CrossRef]

4. Dekker, S.; Cilliers, P.; Hofmeyr, J.-H. The complexity of failure: Implications of complexity theory for safety investigations. Saf. Sci. 2011, 49, 939-945. [CrossRef]

5. Komljenovic, D.; Loiselle, G.; Kumral, M. Organization: A new focus on mine safety improvement in a complex operational and business environment. Int. J. Min. Sci. Technol. 2017, 27, 617-625. [CrossRef]

6. Heinrich, H.W. Industrial Accident Prevention. A Scientific Approach, 2nd ed.; McGraw-Hill: New York, NY, USA, 1941.

7. Hollnagel, E. FRAM: The Functional Resonance Analysis Method: Modelling Complex Socio-Technical Systems; Ashgate Publishing Ltd.: Farnham, UK, 2012.

8. Leveson, N. A new accident model for engineering safer systems. Saf. Sci. 2004, 42, 237-270. [CrossRef]

9. Rasmussen, J. Risk management in a dynamic society: A modelling problem. Saf. Sci. 1997, 27, 183-213. [CrossRef]

10. Reason, J.T. Managing the Risks of Organizational Accidents; Ashgate: Aldershot, UK; Hants, UK, 1997.

11. Lundberg, J.; Rollenhagen, C.; Hollnagel, E. What-You-Look-For-Is-What-You-Find-The consequences of underlying accident models in eight accident investigation manuals. Saf. Sci. 2009, 47, 1297-1311. [CrossRef]

12. Lundberg, J.; Rollenhagen, C.; Hollnagel, E. What you find is not always what you fix-How other aspects than causes of accidents decide recommendations for remedial actions. Accid. Anal. Prev. 2010, 42, $2132-2139$. [CrossRef]

13. Hovden, J.; Størseth, F.; Tinmannsvik, R.K. Multilevel learning from accidents-Case studies in transport. Saf. Sci. 2011, 49, 98-105. [CrossRef]

14. Lukic, D.; Margaryan, A.; Littlejohn, A. How organisations learn from safety incidents: A multifaceted problem. J. Workplace Learn. 2010, 22, 428-450. [CrossRef]

15. Drupsteen, L.; Groeneweg, J.; Zwetsloot, G.I.J.M. Critical Steps in Learning From Incidents: Using Learning Potential in the Process From Reporting an Incident to Accident Prevention. Int. J. Occup. Saf. Ergon. 2013, 19, 63-77. [CrossRef] [PubMed]

16. Stemn, E.; Hassall, M.E.; Cliff, D.; Bofinger, C. Incident investigators' perspectives of incident investigations conducted in the Ghanaian mining industry. Saf. Sci. 2019, 112, 173-188. [CrossRef]

17. Montibeller, G.; von Winterfeldt, D. Cognitive and Motivational Biases in Decision and Risk Analysis. Risk Anal. 2015, 35, 1230-1251. [CrossRef] [PubMed]

18. Hudson, P. Aviation safety culture. Safeskies 2001, 1, 23.

19. Stemn, E.; Bofinger, C.; Cliff, D.; Hassall, M.E. Examining the relationship between safety culture maturity and safety performance of the mining industry. Saf. Sci. 2019, 113, 345-355. [CrossRef]

20. Becker, J.; Knackstedt, R.; Pöppelbuß, J. Developing Maturity Models for IT Management. Bus. Inf. Syst. Eng. 2009, 1, 213-222. [CrossRef]

21. Wendler, R. The maturity of maturity model research: A systematic mapping study. Inf. Softw. Technol. 2012, 54, 1317-1339. [CrossRef]

22. Westrum, R. Cultures with requisite imagination. In Verification and Validation of Complex Systems: Human Factors Issues; Wise, J.A., Hopkin, V.D., Stager, P., Eds.; Springer: New York, NY, USA, 1993; pp. 401-416.

23. Westrum, R. The study of information flow: A personal journey. Saf. Sci. 2014, 67, 58-63. [CrossRef]

24. Hudson, P. Applying the lessons of high risk industries to health care. Qual. Saf. Health Care 2003, 12, i7-i12. [CrossRef]

25. Westrum, R. A typology of organisational cultures. Qual. Saf. Health Care 2004, 13, ii22-ii27. [CrossRef] [PubMed]

26. Fleming, M. Safety Culture Maturity Model; Health and Safety Executive: Norwich, UK, 2001.

27. Fleming, M. Developing Safety Culture Measurement Tools and Techniques Based on Site Audits rather than Questionnaires; Final Project Report; Saint Marys University: Halifax, NS, Canada, 2007.

28. Maier, A.M.; Moultrie, J.; Clarkson, P.J. Assessing Organizational Capabilities: Reviewing and Guiding the Development of Maturity Grids. IEEE Trans. Eng. Manag. 2012, 59, 138-159. [CrossRef] 
29. Filho, A.P.G.; Andrade, J.C.S.; de Oliveira Marinho, M.M. A safety culture maturity model for petrochemical companies in Brazil. Saf. Sci. 2010, 48, 615-624. [CrossRef]

30. Lawrie, M.; Parker, D.; Hudson, P. Investigating employee perceptions of a framework of safety culture maturity. Saf. Sci. 2006, 44, 259-276. [CrossRef]

31. Parker, D.; Lawrie, M.; Hudson, P. A framework for understanding the development of organisational safety culture. Saf. Sci. 2006, 44, 551-562. [CrossRef]

32. Goncalves Filho, A.P.; Waterson, P. Maturity models and safety culture: A critical review. Saf. Sci. 2018, 105, 192-211. [CrossRef]

33. Lindberg, A.-K.; Hansson, S.O.; Rollenhagen, C. Learning from accidents-What more do we need to know? Saf. Sci. 2010, 48, 714-721. [CrossRef]

34. Drupsteen, L.; Hasle, P. Why do organizations not learn from incidents? Bottlenecks, causes and conditions for a failure to effectively learn. Accid. Anal. Prev. 2014, 72, 351-358. [CrossRef]

35. Jacobsson, A.; Ek, Å.; Akselsson, R. Method for evaluating learning from incidents using the idea of "level of learning". J. Loss Prev. Process Ind. 2011, 24, 333-343. [CrossRef]

36. Downe-Wamboldt, B. Content analysis: Method, applications, and issues. Health Care Women Int. 1992, 13, 313-321. [CrossRef] [PubMed]

37. Elo, S.; Kääriäinen, M.; Kanste, O.; Pölkki, T.; Utriainen, K.; Kyngäs, H. Qualitative content analysis: A focus on trustworthiness. SAGE Open 2014, 4, 2158244014522633. [CrossRef]

38. Graneheim, U.H.; Lundman, B. Qualitative content analysis in nursing research: Concepts, procedures and measures to achieve trustworthiness. Nurse Educ. Today 2004, 24, 105-112. [CrossRef]

39. Kondracki, N.L.; Wellman, N.S.; Amundson, D.R. Content Analysis: Review of Methods and Their Applications in Nutrition Education. J. Nutr. Educ. Behav. 2002, 34, 224-230. [CrossRef]

40. Krippendorff, K. Content Analysis: An Introduction to Its Methodology; SAGE Publication Ltd.: Los Angeles, CA, USA, 2013.

41. Schreier, M. Qualitative Content Analysis in Practice; SAGE Publications: Thousand Oaks, CA, USA, 2012.

42. Hudson, P.T.W.; Willekes, F.C. The Hearts and Minds Project in an Operating Company: Developing Tools to Measure Cultural Factors. In Proceedings of the SPE International Conference on Health, Safety and Environment in Oil and Gas Exploration and Production, Stavanger, Norway, 26-28 June 2000.

43. Anglo American Plc. Safety Risk Management Process: SRMP Detailed Journey Workbook; Anglo American Services (UK) Ltd.: London, UK; University of Queensland: Brisbane, QLD, Australia, 2010.

44. Foster, P.; Hoult, S. The safety journey: Using a safety maturity model for safety planning and assurance in the UK coal mining industry. Minerals 2013, 3, 59-72. [CrossRef]

45. Mine Safety Operations Branch. MDG 1010 Minerals Industry Safety and Health Risk Management Guideline; NSW Department of Industry and Investment: Sydney, NSW, Australia, 2011.

46. ICMM. Health and Safety Performance Indicators. Available online: https://www.icmm.com/en-gb/ publications /health-and-safety/health-and-safety-performance-indicators (accessed on 14 January 2017).

47. Australian Standard. Workplace injury and disease recording standard. In AS 1885.1-1990; Australian Standard: North Sydney, NSW, Australia, 1990; p. 28.

48. Amponsah-Tawiah, K.; Mensah, J. Occupational Health and Safety and Organizational Commitment: Evidence from the Ghanaian Mining Industry. Saf. Health Work 2016, 7, 225-230. [CrossRef]

49. Amponsah-Tawiah, K.; Ntow, M.A.O.; Mensah, J. Occupational Health and Safety Management and Turnover Intention in the Ghanaian Mining Sector. Saf. Health Work 2016, 7, 12-17. [CrossRef]

50. Zohar, D. A group-level model of safety climate: Testing the effect of group climate on microaccidents in manufacturing jobs. J. Appl. Psychol. 2000, 85, 587-596. [CrossRef]

51. Rollenhagen, C.; Westerlund, J.; Lundberg, J.; Hollnagel, E. The context and habits of accident investigation practices: A study of 108 Swedish investigators. Saf. Sci. 2010, 48, 859-867. [CrossRef]

52. Kim, Y.; Park, H. An Investigation of the Competencies Required of Airline Cabin Crew Members: The Case of a Korean Airline. J. Hum. Resour. Hosp. Tour. 2014, 13, 34-62. [CrossRef]

(C) 2019 by the authors. Licensee MDPI, Basel, Switzerland. This article is an open access article distributed under the terms and conditions of the Creative Commons Attribution (CC BY) license (http://creativecommons.org/licenses/by/4.0/). 